\title{
POSMODERNIDAD Y OBRA DE ARTE: DE HEIDEGGER A VATTIMO
}

\author{
Biviana Hernández \\ Universidad Austral de Chile. \\ urganda5@yahoo.es
}

\begin{abstract}
Resumen
El presente artículo aborda el debate sobre la posmodernidad conforme la concepción del arte y la experiencia estética, que establece Heidegger al definir la obra de arte como puesta en obra de la verdad, y las teorías de Frederic Jameson y Gianni Vattimo respecto a las características culturales que adopta el sujeto posmoderno, y que coinciden con las de la obra de arte, toda vez que lo estético decanta en una eclosión de su significante gracias a la influencia que juegan en su determinación los medios masivos de comunicación.
\end{abstract}

Palabras clave: modernidad, posmodernidad, obra de arte, experiencia estética.

\begin{abstract}
This essay deals with the debate concerning postmodernity in the light of Heidegger's conception of art and esthetic experience as the putting into effect of truth, and of the theories of Frederic Jameson and Gianni Vattimo regarding the cultural characteristics embraced by the postmodern subject. These agree with the characteristics of works of art insomuch as the esthetic allows the surge of its significant thanks to the influence and role played in its determination by the massive media of communication.
\end{abstract}

KEYWORDS: modernity, post-modernity, work of art, esthetic experience.

$\overline{R A}$ Validando la afirmación de Vattimo, que sostiene que la posmodernidad filosófica es anunciada tempranamente por Nietzsche y Heidegger, ahondaremos en las reflexiones que este último establece en El origen de la obra de arte, respecto a un modo de comprensión del arte más allá de la mera descripción de sus características formales, en una concepción que prevé o anticipa el modo de darse del arte y la experiencia estética en la sociedad tardo-industrial. En este sentido, nos interesa destacar los conceptos y premisas clave del pensamiento filosófico posmoderno, de acuerdo con una interpretación que, lejos de tematizar la situación del arte, complejiza su discusión en torno a las posibilidades que una situación histórica experimentada como tal permite entrever a partir de nociones como desarraigo, oscilación, extrañamiento, ambivalencia, entre otras, que aplicadas a la obra de arte heideggeriana se corresponden con las características mediante las cuales es dable pensar la condición 
posmoderna del arte y la cultura en general. De esta forma, habrá de verse la relación entre la apuesta heideggeriana de una obra de arte como apertura del ser en un nuevo modo de darse del arte, cuyo acontecer estribará en el descubrimiento de una verdad débil (histórica pero intrascendente), con la experiencia estética transformada en la sociedad de masas, que describe Vattimo, y los rasgos del sujeto cultural esquizo de la tercera fase del capitalismo, según Jameson.

\title{
I. El arte en el contexto de la modernidad/posmodernidad
}

En el contexto más general, señalaremos con Alfonso de Toro (1997) que la posmodernidad es un fenómeno histórico-cultural posterior a la modernidad, correspondiendo al último tercio del siglo XX, época del fin de la metafísica -que Vattimo asimila al de la muerte del arte- en la que está en juego no la superación del espíritu absoluto hegeliano, cuanto un remitirse en los varios sentidos que tiene este verbo, esto es:

\begin{abstract}
"Remitirse de una enfermedad, como convalecencia, pero también remitir y remitirse a alguien en el sentido de confiar en alguien [...] En esta época, el pensamiento está respecto de la metafísica, en una posición de Verwindung: en verdad no se abandona la metafísica como se abandona un traje viejo porque ella nos constituye como nuestro destino, nos remite a ella y nosotros nos remitimos a ella como a algo que nos ha sido asignado" (Vattimo 2000, p. 50).
\end{abstract}

Con este remitirse en sentido filosófico, la posmodernidad no debe entenderse como corolario del periodo que la precedió, mera continuación o momento cúlmine de aquél, sino más bien como una actividad que repiensa la tradición cultural occidental de acuerdo con un paradigma de compresión que reacciona contra los discursos totalizantes, al modo de las metanarrativas que describe Lyotard en La condición posmoderna (2000), para fundar una nueva organización del pensamiento y conocimiento humanos en base a la reescritura de la modernidad, privilegiando el aspecto perlaborante $^{1}$ del discurso y, con ello, la actividad de la Verwindung heideggeriana.

1 De Toro explica los procedimientos que exige la actividad perlaborativa: "Es importante tener en cuenta que la elaboración es libre, no tiene primeramente una finalidad, se libra de la asociación, de un estado altamente receptivo, se encuentra en un estado momentáneo de desorden. Describe algo que no se alcanza a comprender, lo único que se sabe con certeza es que se refiere al pasado. El pasado se deconstruye y no se elimina. No se trata de recuperar, de emplear partes del pasado, sino de elaborar y perlaborar ciertos proyectos que por restricciones ideológicas o de otro tipo habían quedado excluidos [...] Re-escribir la modernidad significa elegir y relacionar elementos en forma asociativa sin una metarreflexión. Más bien se describe algo que no se conoce bien, solamente se sabe que ese algo se refiere al pasado [...] Re-escribir la cultura significa haber digerido su pasado de tal modo que el pasado desaparezca como categoría determinante" (1997, p. 16). 
Como reescritura, el discurso posmoderno dialoga con la modernidad, en circunstancias que uno de sus rasgos fundamentales operó la distinción entre cultura de élite y cultura de masas; distinción de la que dependía su función utópica de asegurar, desde los ámbitos de producción cultural, un escenario de auténtica experiencia frente al entorno de una cultura comercial; de allí que la modernidad insistiera en buscar de modo formal la novedad, la innovación y la transformación de las formas antiguas o de la tradición. Así las cosas, el divorcio que ella trajo consigo secundó la determinación de que para ser consideradas modernas las obras dependerían de la categoría de lo nuevo, en tanto que superación, pues su lógica previó la obsolescencia del estilo anterior una vez que la nueva forma lo sobrepasara. Siendo esto así, contarían como modernas las obras que reaccionaran contra lo normativo: la autoridad de la tradición en busca de cambios que expresaran sustantivamente un estado de progreso y utopía, en respuesta a su rechazo hostil contra el mercado. Mientras que el posmodernismo compartiría una sonora afirmación -rayana incluso en lo celebratorio- del mercado en cuanto tal (Jameson 1996).

Como forma de producción entonces, la modernidad percibió lo estético como pura autonomía, puesto que ella se identificó con el cambio, éste con la crítica y la crítica con el progreso (Paz 1987). Mas, quienes defienden esta postura establecerían una retórica de conservación estética o, lo que es lo mismo, una versión conservadora de una gran historia de emancipación; nos referimos a la emancipación del arte del mal gusto. Por eso Calinescu rechaza una interpretación que demonice el mercado, como habría hecho aquélla (y de la que Jameson no escaparía), y que, del mismo modo, exalte acríticamente el espíritu innovador de la modernidad. Un espíritu tal habría acentuado la creencia en la originalidad -concretándose y radicalizándose en las formas de arte vanguardista- en la medida en que estuvo ligado a la noción de progreso y, por tanto, a la de cambio, y el cambio siempre es indicativo de superación crítica. Pero ocurre que esta búsqueda de lo nuevo decantó en la saturación de su principio, dando lugar a aquello que Octavio Paz denominó la tradición de la ruptura, una constante destrucción y reconstrucción, cuestionamiento y superación del discurso moderno. Y cuando esto ocurre, el arte pierde sus poderes de negación o, de modo más radical, sus negaciones se convierten en repeticiones rituales, entiéndase la rebeldía convertida en procedimiento, la crítica en retórica, la transgresión en ceremonia. Modelo que sistematizaría el modo como la negación, vale decir, el poder crítico e irónico del arte moderno, deja de ser creador; hecho que Paz interpreta como el síntoma inequívoco, no del fin del arte, cuanto del fin de la idea de un arte propiamente moderno.

Las vanguardias literarias habrían heredado este espíritu, llevándolo a sus últimas consecuencias, hasta superar el límite de la visión progresista que aquél postulaba, vale decir, hasta su agotamiento, en el que la ruptura como fórmula privilegiada del cambio se transformaría en tradición, quedando no solo la modernidad bajo esta égida, sino también el principio que la sostuvo. Solo en estas condiciones puede entenderse que la vanguardia haya sido la gran ruptura y que con ella se cierre la tradición de la ruptura. En estas condiciones, el arte posmoderno constituiría el fin de las vanguardias y de la tradición de la ruptura y, con ello, la muerte del artista como creador, genio o profeta: "mejor dicho es la última vanguardia, la última ruptura, apagándose en el 
instante mismo de su gestualidad iconoclasta" (Paz 1987, p. 211). En otras palabras, el arte posmoderno constituiría la clausura del arte moderno, en tanto que:

"El suyo es un acto de demolición que derriba los monumentos modernos, pero sin erigir nada duradero en su lugar: un cobertizo quizá, un kiosco, una tienda de campaña... el poeta posmoderno es, por eso, el último de los parricidas: desmitifica a los genios y a los profetas, pero también a sí mismo; no procura emularlos y no se convierte, él también, en padre" (Binns 1999, p. 42).

Corolario de esta imposibilidad de innovar en el ámbito de la literatura y las artes, es para Jameson la pérdida del sentido crítico de la parodia y la preponderancia, en su lugar, del pastiche ${ }^{2}$, figura antitética de aquélla, no obstante la más característica del arte posmoderno. El surgimiento del pastiche obedecería a la desaparición del sujeto individual, siendo la consecuencia formal de un estilo personal, en el que al artista no le quedaría más que imitar estilos muertos. Esta situación es la que describe en el terreno del arte la fase de desarrollo del capitalismo tardío o multinacional, etapa en la que las producciones culturales responden a la práctica azarosa de lo "heterogéneo", "fragmentario" y "aleatorio", experimentado por un sujeto de personalidad esquizoide, característico de la posmodernidad ${ }^{3}$.

Jameson no solo entiende el arte posmoderno despojado de todo poder crítico, también lo concibe a partir de su carácter esquizofrénico, en el sentido del desorden lingüístico descrito por Lacan, que lo conecta con la figura del pastiche, toda vez que lo define a condición de una práctica imprevisible de imágenes y lenguajes que sitúan al artista como un recipiente vacío e impotente de los lenguajes e imágenes que lo atraviesan, de allí que, la palabra entera del esquizofrénico pierda todo sentido, esto es, la potencia para expresar un efecto incorporal distinto de las acciones y pasiones

2 "El pastiche es, como la parodia, la imitación de un estilo peculiar o único, idiosincrásico; es una máscara lingüística, hablar un lenguaje muerto; pero es una práctica neutral de esta mímica, no posee las segundas intenciones de la parodia; amputado su impulso satírico, carece de risa y de la convicción de que, junto a la lengua anormal que hemos tomado prestada por el momento, todavía existe una sana normalidad lingüística. el pastiche es, entonces, una parodia vacía, una estatua ciega" (Jameson 1996, p. 38).

3 Recurriendo a la concepción lacaniana del esquizofrénico, Jameson define al sujeto posmoderno conforme la situación de un individuo que no tiene la capacidad de producir relaciones entre significantes o, mejor dicho, que cerebralmente ha producido una ruptura en la cadena de significantes (temporales, espaciales, etc.); "con la ruptura de la cadena significante el esquizofrénico queda reducido a una experiencia de puros significantes materiales o, en otras palabras, a una serie de presentes puros y sin conexión en el tiempo" (Op. cit., p. 48). 
del cuerpo; entiéndase, un acontecimiento ideal distinto de su propia efectuación presente $^{4}$.

Conforme lo anterior, pastiche y esquizofrenia designarán los rasgos que permiten identificar la condición estética del arte posmoderno, pero tratándose de categorías que definen arbitrariamente su estatuto, conviene detenerse en la explicación que les otorga el autor, en circunstancias que le permiten conceptualizarlo a la luz de su oposición y distancia crítica respecto del arte moderno. Primero, considerando la noción de esquizofrenia, la obra posmoderna consistirá en una serie de significantes aislados y yuxtapuestos en algo semejante a un collage, en el que se hará extensiva la función de diferenciación por sobre la de unificación, puesto que lo que importa en ella no es tanto la búsqueda de la unidad en pos de una creación novedosa, única y original, cuanto la diferencia más allá o a pesar de cualquier intención autorial, advierte Jameson. Ello explicaría la idea de un arte posmoderno como un surrealismo sin el inconsciente, que hace prevalecer la superficialidad en la libre asociación de un sujeto colectivo impersonal, "sin la carga y la inversión de un Inconsciente personal ni grupal [...]. Es un surrealismo en último término, bastante realista, dada su incorporación de la lógica de las sociedades contemporáneas" (1996, p. 107). Superficialidad que bien podemos relacionar con la idea del cuerpo esquizofrénico deleuzeano, que éste recupera del psicoanálisis freudiano, a saber: una especie de cuerpo-colador, cuerpotroceado o cuerpo-disociado. Cuerpo que, en cuanto tal, ya no es sino profundidad, "bien en la grieta profunda que atraviesa el cuerpo, bien en las partes troceadas que se encajan y giran” (Deleuze 2005, p. 118).

Por otra parte, el carácter esquizofrénico del arte posmoderno, según Jameson, tiene que ver con el influjo de los mass media, fundamentalmente de la televisión y el video, en la medida en que la imposibilidad de encontrar puntos de contacto entre los elementos yuxtapuestos en el texto obedece a la sobresaturación de información, a la interacción incesante y aleatoria de los distintos signos culturales que lo emplazan como un flujo total que no para y no deja lugar ni tiempo al gesto hermenéutico. Aquí, la noción de texto bien puede ampliarse hacia la comprensión de cualquier producto cultural en general, como artístico en particular.

Respecto de este debate, Calinescu expone una comprensión metafórica del posmodernismo, al concebirlo conforme la figura del rostro, una cara de la modernidad que representa la asociación con una modernidad más grande y con su espiritu. De hecho, "si no fuera por esta gran modernidad, las similitudes parciales y las diferencias expresivas de estas caras se disolverían y perderían el significado" (1991, p. 301). Eludiendo interpretar la posmodernidad como una etapa que supera la modernidad, estimula una reflexión que la confine a ser una fase similar a otras que ha adoptado de acuerdo con el curso de la historia, así la decadencia, la vanguardia o el kitsch. En concordancia con ellas, el posmodernismo resultaría una perspectiva desde la cual

4 Para una concepción del sentido conforme la serie del "esquizofrénico y la niña", cf. G. Deleuze 2005. 
es posible preguntar acerca de la modernidad y sus diversas encarnaciones, toda vez que se lo concibe como una subcategoría de la vanguardia o, si se quiere, como la reencarnación contemporánea de la "vieja vanguardia". Para el autor, entre las caras de la modernidad, el posmodernismo resulta la más estrambótica, "autoescéptica pero curiosa, no creyente pero buscadora, benevolente pero irónica (Ibíd., p. 271). Mientras que con Niall Binns, afín a la tesis de Paz, tenemos que, no siendo su fase última, lo posmoderno aparece en el arte cuando la novedad se diluye al perder trascendencia como valor, esto es, cuando desaparece la novedad en tanto que concepto fundacional en el gran relato del progreso material, tecnológico y moral de la humanidad. Así, junto a Lytorad, podríamos decir incluso que la postmodernidad, en cuanto que condición referida al estado de la cultura y, más específicamente, del saber, no es posterior a la modernidad, cuanto un estado naciente dentro de la misma.

Y si con Jameson la posmodernidad es lo que queda una vez que el proceso de modernización ha concluido, entonces el estado de la cultura en las sociedades posindustriales ${ }^{5}$ se caracterizará por la producción de conocimientos productivos, un nuevo modo de producción, en el que la ciencia y la técnica ocuparán el lugar central que antaño tuvo la industria. Dado lo cual, la cultura se tornará un producto por derecho propio, el mercado un sustituto de sí mismo y una mercancía como cualquiera de los productos que él genera, mientras que la modernidad era la crítica de la mercancía y el esfuerzo por conseguir que ésta se trascendiera a sí misma (Jameson 1996). En consecuencia, ha de entenderse el posmodernismo, en un escenario de cambio social, como producto cultural del surgimiento de una nueva etapa en el desarrollo del capitalismo tardío (consumista o multinacional), impregnándose de un carácter histórico más que formalista al concebírselo no como un estilo más entre otros, sino como la dominante cultural de la lógica del capitalismo tardío, que no es un orden social completamente nuevo, cuanto "la parte concomitante de una modificación sistémica más del propio capitalismo" (Ibíd.), en tanto que supone el intento dialéctico de pensar el presente dentro del curso de la historia. La posmodernidad, por tanto, no es la fase que continúa a la modernidad, antes bien, la precede y prepara, si aceptamos que ella constituye una ruptura cultural y de la experiencia humana, producto de las nuevas formas de producción y organización económicas que produjo la exacerbación del capitalismo en su tercera fase de desarrollo. Mas, no olvidemos que tal lectura obedece a la de un pensador neomarxista que critica el hecho de que lo posmoderno responda y, en el peor de los casos, coincida con la fórmula que define la lógica del capitalismo, esto es, la producción de mercancía y las nuevas formas de organización empresarial, que

5 Jameson opta por utilizar la noción de capitalismo tardío, multinacional, de consumo o de los media, para señalar su dependencia en la tradición de la escuela de Francfort, y para rechazar las connotaciones conservadoras que percibe en la noción de "sociedad postindustrial" utilizada por Lyotard.

6 Ello responde al hecho de una periodización cultural conforme los tres periodos fundamentales del capitalismo que el autor identifica: de mercado (realismo), de monopolio o imperialista (modernidad) y multinacional o de consumo (posmodernidad). 
lo llevan a interpretar cómo el abandono de lo estético, su falta de preocupación o, lisa y llanamente, el carácter anti-estético del posmodernismo es lo que ocasiona la pérdida del sentido crítico de las obras modernas, atribuyéndole a aquél un estado de ser parásito, reducido a poco más que una imitación neutra sin sentido lúdico, homólogo a la figura del pastiche:

"Como una clase domesticada de (anti)modernismo, confinada a un textualismo circular inevitable y sin querer distinguir entre lo estético y lo no estético, el posmodernismo no puede evitar representar, aunque sea inconscientemente, el papel de reforzador de la lógica del capitalismo de consumo" (Cit. en Calinescu 1991, p. 284).

Y si bien Jameson no logra explicar en qué medida y bajo qué recursos el posmodernismo reproduce la lógica del capitalismo tardío, consciente de las limitaciones que implica su punto de vista en la elaboración teórico filosófica del problema, sugiere su contraparte en la cuestión significante de ver, así como el posmodernismo refuerza la lógica del capitalismo de consumo, en qué medida éste podría sustraerse o resistir a esta misma lógica. Cuestión que por cierto no resuelve, pero que abre la posibilidad de reflexionar en torno a otras perspectivas desde las cuales comprender la posmodernidad, cual encarnación o un rostro más de la misma en la perspectiva de Calinescu.

\section{La posmodernidad según la propuesta de Gianni Vattimo: pensamiento débil y mass media}

El pensamiento de Vattimo obliga a pensar la posmodernidad, tanto como el discurso en torno a ella, dentro de una historia, cual es la del fin de la modernidad, que no es la superación cuanto su clausura. Trátase de una historia en la que aparece el nihilismo como centro neurálgico, en la medida en que concilia las concepciones nietzscheanas y heideggerianas para la comprensión de una era de la poshistoricidad y de la muerte de la metafísica o postmetafísica, en la que cobra sentido la noción de pensamiento débil como un modo de reflexión típicamente posmoderno, opuesto al de la metafísica, en tanto que pensamiento fuerte: atemporal, dominante y universal. De tal suerte, el pensamiento débil que postula Vattimo responde a una concepción historicista nihilista, que lo define no como un pensamiento de la debilidad, sino como del debilitamiento del ser, equivalente a un pensar fundacional o, lo que es lo mismo, de la metafísica en todos los órdenes epistemológicos y experienciales, suponiendo el reconocimiento de una línea de disolución en la historia de la ontología.

Con la noción de pensamiento débil, Vattimo articula las bases para una nueva comprensión de la posmodernidad, al tiempo que prepara la emergencia de un nuevo discurso en torno a su debate. Con ella deja de tener validez toda pretensión normativa, universalizante, edificante y/o progresista, en tanto que sistematiza la idea del ser como devenir y ser-ahí (de acuerdo con la concepción del Dasein heideggeriano), en su caducidad y duración, que no es, sino que acaece y que, en última instancia, señala 
la experiencia de una nueva ontología para la cual la verdad se sitúa en un horizonte débil, de carácter retórico, toda vez que el ser se experimenta desde el extremo de su ocaso y disolución.

Para Oñate (1990), el problema de un pensamiento débil constituye el eje aporético de toda posible filosofía actual o no-metafísica, en circunstancias que se apoya en el nihilismo nietzscheano y heideggeriano para sostener un hilo de continuidad fundamental a partir del que sea posible postular la experiencia del sujeto posmoderno como una experiencia en la que el nihilismo no es una nueva etapa en la historia de la modernidad cuanto su destino. Entiéndase nihilismo más allá de la disolución de los valores "fuertes" e imposibilidad de la verdad, como una nueva estructura de pensamiento: del ser capaz de sobrepasar la metafísica, de pensar el ser como evento y, en última instancia, "como el configurarse de la realidad particularmente ligado a la situación de la época” (1990, p. 34).

Descrita la situación del fin de la modernidad, cabe preguntarse por el curso que sigue a este ocaso que experimenta el pensar metafísico y sus valores, acorde con el pensamiento fuerte de la historia y la verdad. Con Vattimo, el itinerario que indica la respuesta establecerá como único camino posible el de la poshistoricidad que, a su vez, significa el derrotero nihilista, de disolución, liquidación, debilitamiento del ser y sus categorías fuertes; "así pues, no el ser fuerte de la metafísica, sino un ser débil, despotenciado, que deviene, nace y muere, se da ahora a nuestra experiencia epocal y al pensar, como única indicación posible" (Ibíd., p. 43). En estos términos, ha de entenderse la posmodernidad conforme la máxima que reza: experimentar el nihilismo es la única posible vía de la ontología, en cuyas condiciones el destino de la metafísica -aciago para quienes aún buscan fundamentos- vendría a sintetizar la situación existencial de la posmodernidad en una suerte de metáfora invertida, donde el metarrelato de la historia del ser que progresa hacia su total plenitud es desplazado por el relato del ser que da cuenta del proceso inminente de su disolución hasta su más completa extinción. Si no, revisemos la siguiente cita del autor:

"Si las raíces de la violencia metafísica están en último término en la relación autoritaria que establecen entre el fundamento y lo fundado, entre el ser verdadero y la apariencia efímera, y en las relaciones de dominio que se constituyen en torno a la relación sujeto-objeto, la cuestión concerniente a ultrapasar este pensamiento y el mundo que determina, no podrá plantearse como acceso a ningún otro fundamento desde el que iniciar una nueva construcción [...], sino como un reemprender y proseguir el proceso disolutivo y nihilista que caracteriza el devenir de la metafísica y la modernidad" (Ibíd., p. 45).

Por otra parte, para Vattimo, lo posmoderno solo tiene sentido en la medida en que refiera el hecho de que la sociedad en la que vivimos sea una sociedad de la comunicación generalizada, esto es, la sociedad de los mass media. Una tesis que estimula pensar que, por lo menos en lo que concierne a ciertos aspectos, la modernidad 
ha concluido. Mas, ello solo si la concebimos como la época en la que el hecho de "ser moderno" constituye un valor fundamental.

El autor recurre a la situación del arte para mostrar de qué manera la noción de genio creador es la que mejor expresa la condición moderna, parafraseando a Lyotard: el culto por lo nuevo y lo original, en directa reacción contra la tradición y el pasado, que implican en este ámbito la imitación de modelos clásicos. No obstante, este culto de lo nuevo y original se da acompañando o, más bien, en paralelo a una perspectiva más general, que considera la historia humana como un proceso continuo de superación y emancipación. De acuerdo con ella, la condición para concebir la historia como realización progresiva de la humanidad es la posibilidad de que sea vista y entendida como un proceso unitario, en consecuencia con la idea de que solo si existe la historia se puede hablar de progreso. Entendido así, la modernidad se acabaría cuando deja de ser posible ponderar la historia como algo unitario, pues tal visión supone la existencia de un centro alrededor del cual se reunieran y organizaran los acontecimientos, en circunstancias que tales acontecimientos constituyen no más que representaciones arbitrarias, sea del pasado en su totalidad, o sea de acontecimientos particulares de la historia. Situación que ya habría demostrado la filosofía a lo largo de los siglos XIX y $\mathrm{XX}$, con su crítica a la idea de una historia ${ }^{7} \mathrm{y}$, junto a ella, con la pregunta acerca de qué es aquello que verdaderamente se transmite del pasado ${ }^{8}$, al articular una concepción pluralista y alternativa de la historia, en tanto descreimiento de una sola historia, o bien, de una historia única, válida para todas las culturas y sociedades.

Esta nueva concepción obligó a entender la historia como síntesis de imágenes del pasado, propuestas desde diversos puntos de vista, dado lo cual "resultaría ilusorio pensar que exista una perspectiva universal y suprema capaz de unificar todas las restantes" (Vattimo 2000, p. 76). En consecuencia, si el principio fundamental para sostener la idea de progreso era la búsqueda de un determinado tipo de hombre conforme la determinación de un cierto tipo de valores, él entrará en crisis, del mismo modo como le ocurrió a la idea de una historia, puesto que "si no hay un curso unitario de las vicisitudes humanas no podrá sostenerse tampoco que éstas avancen hacia un fin, que efectúen un plan racional de mejoras, educación y emancipación" (Ibíd., p. 76).

Otro elemento determinante para el fin de la modernidad, sumado al de la crisis en la concepción unitaria de la historia y la consecuente crisis de la idea de progreso, es el advenimiento de la sociedad de comunicación, un rasgo sin duda clave para el entendimiento de la posmodernidad, si se piensa que solo en este tipo de sociedad tiene sentido el debate en torno a lo posmoderno. Mas, para entender su lógica hay que tener presente que la imposibilidad de pensar la historia como un curso unitario se debe, en mayor medida, a la aparición de los medios de comunicación de masas, toda vez que ellos han determinado la disolución de los grandes relatos en el sentido de Lyotard; una idea que bien puede expresar la situación de la radio, la televisión

\footnotetext{
$7 \quad$ Cf. Peter Burke 2003.

$8 \quad$ Cf. Arthur Danto 1989.
} 
y la prensa, en tanto factores de una explosión y multiplicación generalizada de Weltanschauungen o de visiones de mundo, que hacen que la lógica de un mercado de la información reclame una continua dilatación de su esfera, en pos de lograr que "todo" adopte la forma y la función de un objeto de comunicación:

"Esta multiplicación vertiginosa de la comunicación [...] constituye el efecto más evidente de los mass media, siendo, a la vez, el hecho que determina (en interconexión con el fin del imperialismo europeo, o al menos con su transformación radical) el tránsito de nuestra sociedad a la posmodernidad" (Vattimo 1990, p. 80).

En este contexto, el pensador italiano explica que el sentido de la expresión que utiliza como enunciado para el título del libro, La sociedad transparente, es justamente la posibilidad del sinsentido que ella sugiere. Así, valiéndose de la sentencia nietzscheana de que el mundo verdadero se transforma en fábula, señala que:

"Si nos hacemos hoy una idea de la realidad, ésta, en nuestra condición de existencia tardo-moderna, no puede ser entendida como un dato objetivo que está por debajo, o más allá, de las imágenes que los media nos proporcionan. ¿Cómo y dónde podríamos acceder a una tal realidad "en sí"? Realidad, para nosotros, es más bien el resultado del entrecruzarse, del "contaminarse" de las múltiples imágenes, interpretaciones y reconstrucciones que compiten entre sí, o que, de cualquier manera, sin coordinación central alguna, distribuyen los media" (Ibíd. $81)$.

Una explicación así secunda otra de mayor determinación para el ámbito en que nos es pertinente hablar de posmodernidad: la de que la sociedad de la comunicación generalizada se orienta a la fabulación nietzscheana del mundo, si entendemos por tal el proceso mediante el cual las "imágenes del mundo" proyectadas por los media constituyen la objetividad de aquél, más allá de toda interpretación pensada como realidad(es) fijada de antemano. Siendo esto así, resulta fácil creer que lo que se denomina "realidad del mundo" es algo que se constituye como contexto de las diversas, múltiples y potenciales fabulaciones que respecto del mundo caben sugerir o proponer.

La fuerza de esta interpretación es tal, que Vattimo llega a concebir los medios de comunicación como los medios de las masas, en el supuesto de que constituyen la esfera pública del consenso, al adoptar una función estética que imprime al sujeto un sentido de correspondencia o de pertenencia con el grupo social. Esta situación es la que describe la idea de la muerte del arte como explosión de lo estético en base a una forma de autoironización de la producción artística y negación de los lugares de valor tradicionalmente asignados a ella; lo que a la postre significa, por una parte, el fin del arte como hecho específico (en un sentido utópico), y, por otra, la estetización de la cultura en tanto que ampliación del dominio que ejercen los mass media (lo que señalaría el sentido débil del arte, tal como la verdad y el pensamiento). Mas, para estar de acuerdo con esta explicación, tendremos que validar primeramente el intento de disolución heideggeriano del ser como presencia, fundamento y/o permanencia; tanto 
como la tesis de Nietzsche, que sostiene que la imagen de una realidad organizada de acuerdo con un fundamento último es solo un mito tranquilizador, propio de una humanidad todavía "bárbara y primitiva", que se vale de la metafísica como un arma de lucha contra toda situación que amenace la estabilidad de sus principios.

\section{De la obra de arte heideggeriana a la experiencia estética posmoderna}

La instalación e influencia de los mass media en la sociedad de la comunicación descrita por Vattimo, trae aparejada un cambio en las condiciones de producción y recepción cultural, toda vez que aquéllos modifican de modo sustancial el Wesen del arte, entendido en términos heideggerianos, no como la permanencia de un valor estético o su esencia, sino como el modo de darse del arte en la época actual.

La creencia en un mundo y, por tanto, en una historia unitaria, responde a su vez a la utopía moderna y al mito del progreso en el curso de la historia; utopía que, en términos estéticos, actúa en la posmodernidad, desplegándose como heterotopía ${ }^{9}$, como el reconocimiento de espacios y modelos que "hacen mundo", en la medida en que, por un lado, éstos se dan explícitamente en la realidad; y, por otro, su connotación de realidad obedece a la presencia de espacios que describen realidades múltiples. En consecuencia, la capacidad de la obra de arte para hacer mundo descansa en una concepción plural, que determina el sentido heterotópico pensado por Vattimo, tratándose de una obra que es exposición o, si quiere, fundación "del" mundo y no de "un" mundo. Fundamental resulta aquí advertir el cambio en las preposiciones, en circunstancias que esa exposición/fundación remite a los mundos posibles como constitutivos del ser mismo, esto es, como acontecimientos o acaeceres, siempre diferentes del ser.

En la introducción que precede a El fin de la modernidad, Vattimo aclara de qué manera la noción de posmodernidad describe la situación histórica de la era posmetafísica, aquélla en que se disuelven los fundamentos que organizaron la historia del pensamiento moderno y con ellos el ideal de progreso, en tanto que apropiación y reapropiación del ser; de allí que la comprensión del fin de la modernidad sistematice el sucesivo abandono de la modernidad en su lógica de progreso y superación crítica, que en el contexto de la posmodernidad sintetizan el descreimiento de las estructuras estables del ser, en la medida en que se le concibe como un evento que acaece conforme la historicidad del Dasein y, por tanto, del ser para la muerte heideggerianos. De tal suerte, una concepción posmetafísica de la verdad encontrará asidero en la experiencia del arte y la retórica, acorde con la idea nietzscheana del mundo convertido en fábula, puesto que se trata de un mundo en el que todo valor se estima como valor de cambio generalizado. No obstante, estos valores se dejan percibir como "relatos", 
en situación del ser disuelto en la experiencia anti-utópica -aunque quizá resulte más adecuado decir heterotópica- del "discurrir" del valor de cambio. Ésta es, en sus últimas consecuencias, la situación del nihilismo acabado, que termina liquidando los valores metafísicos de la modernidad. Una muerte que es expresión de la crisis del humanismo, dentro de las circunstancias que hacen que sujeto y objeto dejen de contraponerse, bajo el supuesto de que una de las condiciones del pensamiento en la era posmoderna es la experiencia de Ge-Stell, esto es, del ser no solo despojado de todo carácter metafísico, sino también, y en lo sustantivo, des-ocultado al sujeto.

$\mathrm{Y}$ es justamente en este contexto donde conviene revisar la concepción de obra de arte como puesta en obra de la verdad, que erigiera Heidegger en su opúsculo El origen de la obra de arte (1935/36), con la cual, lejos de postular que esta concepción pueda llamarse posmoderna o que su autor represente a dicho periodo, lo que sostenemos es que la puesta en obra de la verdad prevé o anticipa algunos de los rasgos fundamentales a partir de los cuales nos es posible entender la experiencia estética posmoderna. Para ello, dando crédito a la interpretación de Vattimo, hemos de considerar primero que este darse del arte en la época tardo-industrial, se define mediante la realización del conflicto que encarnan las dos dimensiones constitutivas de la obra: la exposición del mundo y la pro-ducción de la tierra, conforme su carácter de cosa o su coseidad, en su determinación como algo ente; y en cuanto que tal, como materia, sustrato y campo, que estimula pensar que la esencia del arte consiste en ese poner en obra la verdad de lo ente:
“ $\mathrm{O}$ es que al decir que el arte es el ponerse a la obra de la verdad vuelve a cobrar vida aquella opinión ya superada según la cual el arte es una imitación y copia de la realidad? [...] La coincidencia con lo ente se considera desde hace mucho tiempo como la esencia de la verdad. Pero ¿acaso opinamos que el mencionado cuadro de Van Gogh copia un par de botas campesinas y que es una obra por- que ha conseguido hacerlo? [...] Nada de esto. En la obra de arte no se trata de la reproducción del ente singular que se encuentra presente en cada momento, sino más bien de la reproducción de la esencia general de las cosas" (Heidegger 1935/1936, p. 26).

Siendo así, habrá de entenderse que la verdad obra en la obra o, mejor dicho, que lo que obra dentro de la obra es el acontecimiento de la verdad, en tanto que apertura de lo ente en su ser, o, si se quiere, des-ocultamiento de lo ente. Vale decir que la obra deja acontecer el desocultamiento de la verdad en la medida en que ella "es el desocultamiento de lo ente en su totalidad" (Ibíd., p. 58). De modo que, retomando sus dimensiones, mundo y tierra, Heidegger explica que:

"El mundo es la abierta apertura de las amplias vías de las decisiones simples y esenciales en el destino de un pueblo histórico. La tierra es la aparición, no obligada, de lo que siempre se cierra a sí mismo y por lo tanto acoge dentro de sí. Mundo y tierra son esencialmente diferentes entre sí y, sin embargo, nunca están separados. El mundo se funda sobre la tierra y la tierra se alza por medio del mundo" (Ibíd., p. 35). 
En estas condiciones, la obra ejerce sobre el espectador un efecto de Stoss o choque (Vattimo 1990), determinante en la concepción del nuevo Wesen del arte. Lo que genera para Heidegger este efecto de impacto es el hecho de que la obra de arte señale la posibilidad de ser, pues, como el Dasein mismo, ésta no es permanencia cuanto evento y apertura del ser-ahí. Dicho en otras palabras, la obra es puesta en obra de la verdad por significar algo más que arte, más que forma acabada, bella o perfecta, producto de un acto creativo, en la medida en que esa puesta en obra es su función de apertura de la verdad en tanto que acontecer del ser, "cuya esencia de evento reside en ser atropellado y "expropiado" en el juego de espejos del mundo" (Vattimo 2000, p. 47).

$\mathrm{Y}$ en tanto que cosa, referida a otra, ya como efecto, causa o instrumento, es decir, siendo parte del mundo como tal y en su conjunto, no remite a nada, puesto que es insignificante. Mas, cómo entender esta afirmación: aceptando el hecho, primero, de que el mundo sea; y, segundo que, como tal, él solo es expresión de gratuidad. Solo si se acepta tal cosa podremos comprender que el encuentro con ese mundo sea para el Dasein una experiencia de extrañamiento; experiencia que señala que la obra de arte no se deja reducir a un esquema preestablecido de significados, puesto que ella no puede deducirse de aquéllos como si fueran su consecuencia lógica. No obstante, la conjunción de estas dos condiciones explica la tesis heideggeriana de la obra de arte como fundadora de mundo(s): como apertura histórico-eventual del ser, apertura que entraña la posibilidad del Stoss como el poner en suspenso la obviedad del mundo o, si se quiere, el de suscitar "un preocupado maravillarse por el hecho, de por sí insignificante (en sentido riguroso: que no remite a nada, o remite a la nada), de que hay mundo" (Ibíd., p. 141).

Y si esta apertura define la situación histórico-eventual de la obra de arte, determinará también la apertura ontológico epocal del ser, toda vez que ella señala las cualidades de extrañamiento y desarraigo de la experiencia estética. Para Vattimo, esta experiencia exige una labor de readaptación, pero que no se propone alcanzar un estadio final de recomposición acabada; la experiencia estética, al contrario, se orienta a mantener vivo el desarraigo, sentencia el filósofo. Siendo así, entiende que no tendría sentido suponer que para Heidegger la experiencia del desarraigo estético hubiera de concluir en una recuperación de la familiaridad y la obviedad, como si el destino de la obra fuese transformarse, al final, en un simple objeto de uso. A este respecto, hay que entender que la situación de desarraigo es constitutiva y no provisional de la obra de arte.

Esta comprensión/aceptación es particularmente decidora de la experiencia estética posmoderna, ya que se trata de una postura que se distancia de las reflexiones tradicionales sobre el arte y lo bello, en que la experiencia estética parecía depender de la Geborgenheit, esto es, el describir siempre una situación de superación, en términos de integración y reintegración, en la que se encarnaría la posibilidad de que la obra sea estabilidad y perennidad, profundidad y autenticidad de una experiencia productiva, fruto de la subjetividad de las facultades anímicas. Así, contra la nostalgia de la eternidad de la obra y la autenticidad de la experiencia, hay que reconocer que 
el Stoss es todo lo que queda de la creatividad del arte en la época de la comunicación generalizada, esto es, el desarraigo y la oscilación de la experiencia estética.

La noción de oscilación ha de entenderse con Vattimo como desfondamiento, en oposición a la fundación de mundo que establece la obra de arte en la concepción de Heidegger. Si ella representa la apertura y la fundación de mundos posibles, su alcance estriba en la experiencia de desfondamiento de la obra, si pensamos que la dimensión de exposición de un mundo entronca con la de fundación, en tanto que la de pro-ducción de la tierra con la de desfondamiento. El hecho es que la oscilación describe el modo de realizarse la obra de arte como conflicto entre mundo y tierra y, en tal sentido, como Stoss o, si se quiere, el Wesen del arte en los dos sentidos que esta noción implica, a saber: el modo de darse la experiencia estética en la posmodernidad o modernidad tardía, y lo que se muestra esencial para el arte tout court, su acontecer como nexo de fundación y desfondamiento, en forma de oscilación y desarraigo; en última instancia, como práctica de mortalidad conforme la situación del ser para la muerte heideggeriano.

Veamos ahora de qué manera Vattimo sintetiza la concepción de obra de arte como puesta en obra de la verdad:

"El mundo expuesto por la obra es el sistema de significados que ésta inaugura, la tierra es producida por la obra en cuanto emerge y se muestra como el fondo oscuro, jamás enteramente agotable en enunciados explícitos, en el que arraiga el mundo de la obra. Si el desarraigo es el elemento esencial y no provisional de la experiencia estética, de tal desarraigo es mucho más responsable la tierra que el mundo; sólo porque el mundo de significados desplegados por la obra aparece oscuramente enraizado (y, por tanto, no lógicamente "fundado") en la tierra, la obra produce un efecto de desarraigo: la tierra no es el mundo, no es un sistema de conexiones significativas, sino lo otro, la nada, la universal gratuidad e insignificancia. La obra es fundación sólo en cuanto produce un continuo efecto de extrañamiento, jamás recomponible en una Geborgenheit final" (2000, p. 144).

Según lo anterior, el significando desarraigante de la obra de arte se corresponderá con el carácter oscilante de la experiencia estética posmoderna. Del mismo modo, ella buscará su lugar en el mundo superando su propia entidad, al pertenecer al ámbito que se abre a través de sí, porque el ser obra de la obra solo existe en esa apertura que ella misma deja al descubierto; apertura que actualiza, en su acontecer, la experiencia de fundación de un mundo, que no es sino la pugna entre mundo y tierra como valores donde la verdad se sabe intrascendente o carente de fundamentos que apelen a trascendencia alguna, en el entendimiento de que el mundo al que remiten es un mundo ordinario.

Así, el poner en obra la verdad opera la experiencia estética posmoderna, toda vez que nos es dable asimilar esta efectuación con la interpretación de Vattimo acerca de la sociedad de los mass media, pues la apertura de lo ente, el acontecer de la verdad que permite el encuentro del mundo con la tierra, se resuelve en el impacto o Stoss que provoca su desfondamiento, como revelación de un mundo vacuo, que fuera de la historia no ofrece nada sólido, ni verdad ni fundamentos. Ello, debido a que en la 
época de los mass media muere el arte vía imposición de la técnica y reproductividad de la máquina, eliminado todo discurso sobre el origen y el genio, tanto como la producción individual de las obras de arte; siendo ahora aquéllos los que, en lugar del artista o del sujeto creador, asumen la función de lo estético.

En suma, de acuerdo con la noción heideggeriana de la obra de arte como puesta en obra de la verdad (verdad como evento y acaecer), es posible describir la condición posmoderna en el terreno del arte y la cultura en general, si se piensa en la disolución de la historia a través de una concepción no-metafísica o posmetafísica de la verdad; concepción que encuentra fundamento en la experiencia del arte y la retórica, que sitúan esta verdad conforme la situación del Dasein, la Verwindung y el Wesen del arte de acuerdo con una experiencia fabulizada de la realidad, que solo es posible ver en una sociedad en que el ocaso de la metafísica conlleva la muerte de la historia y, con ella, la de la concepción unitaria que confiaba en el progreso y el avance de la humanidad hacia un final utópico, ya de emancipación, libertad o felicidad. Siendo esto así, en la concepción del arte posmetafísico existe una ambigüedad en torno a su estatuto, en tanto que se define como una experiencia histórica de fundación de mundos posibles, pero cuya vida depende de los distintos modos en que la obra puede morir, es decir, en la medida en que su acontecer es condición del ser para la muerte y, por ende, del desarraigo que promueve la apertura histórico-eventual del ser y del ente hacia una experiencia de extrañamiento y oscilación; valores con los que interpreta Heidegger la obra de arte, pero que apuntan a definir la situación tanto existencial como histórico-cultural del sujeto posmoderno en la era del capitalismo tardío.

Así las cosas, diremos que la obra de arte como expresión de una cualidad estética fundadora de historia anticipa modos de existencia histórica a condición de depender, referirse o remitirse a la mortalidad y al desarraigo de y en un mundo carente de fundamentos, pero que gracias a la reapropiación del mundo (como re-escritura), llevada a cabo por la Verwindung, vuelve a ser significado, ahora sobre la base de una sociedad técnica y tecnologizada, en que los media dominan los ámbitos de producción cultural una vez que ponen coto a la idea de una historia unitaria y a los valores metafísicos del ser.

\section{A modo de conclusión}

La teorización filosófica en torno a la posmodernidad adquiere validez solo si aceptamos que el fin de la modernidad sintetiza el esfuerzo por sustraerse a la lógica de superación, progreso e innovación, que acarrea el ocaso del ser metafísico tras el abandono de la creencia utópica, que consideraba el curso de la historia como conducente a un destino final en etapas sucesivas de progreso material y espiritual. La estructura de pensamiento que está detrás de esta nueva situación histórico-cultural hurga tanto en la condición como en la situación misma del ser que vive no una época posterior a la modernidad, cuanto una en la que se ha disuelto la idea de historia como relato de una interpretación unitaria del pasado y la humanidad. Esta concepción, a 
su vez, cobra sentido dentro de la filosofía de Nietzsche y Heidegger, autores que anuncian la situación posmoderna desde reflexiones que señalan la cualidad narrativa o fabuladora del mundo del valor de cambio, la condición retórica de la verdad y los relatos de la historia, el nihilismo como destino, la historicidad del Dasein en tanto que ser para la muerte, el humanismo en crisis tras la concepción quimérica y superflua de todo fundamento y la experiencia estética como nuevo Wesen o darse del arte conforme el carácter de acontecer (Ereignis) de las obras de arte. De acuerdo con estas cualidades, la condición de existencia del sujeto posmoderno estará dada por su debilitamiento - que no su debilidad-, en la medida en que tal condición establece la posibilidad de una existencia propiamente posmoderna conforme el abandono de las estructuras estables del ser, que, pensado metafísicamente, imponía al pensamiento y a la existencia la tarea de fundarse o de establecerse en el dominio de lo que no evoluciona, permaneciendo fijo de una vez y para siempre.

No obstante, de acuerdo con el problema planteado en este artículo, lo relevante para la comprensión de la posmodernidad es la forma como se entiende la obra de arte y la experiencia estética posmoderna a partir de las reflexiones de Heidegger, interpretadas por Vattimo, en torno a la era posmetafísica, en que juega un rol determinante la repercusión de los medios masivos de comunicación; los que, al multiplicar los centros históricos o los lugares desde donde se accede a la información, generan redes o núcleos de identidad que aniquilan la pretensión unitaria y universal de una escritura histórica válida para toda la humanidad. Los mass media, también así la verdad histórica, pasan a constituir una experiencia retórica, acorde con un pensamiento débil, donde la verdad importa en la medida en que recrea el discurso, las formas y mecanismos lingüísticos de expresión por medio de los cuales éste se genera. Siendo así, cae en descrédito la concepción metafísica de la verdad, pues, dependiendo ahora de las reglas de la retórica, fuera de ella ya no hay nada que pueda dominar en la escritura y conocimiento de la historia.

Por otra parte, a raíz de la disolución de la noción de fundamento de la verdad como conclusión nihilista para abandonar la modernidad, la concepción heideggeriana de la obra de arte tiene mucho que decir respecto a la experiencia estética posmoderna. Por una parte, si durante la modernidad el arte estaba determinado por la búsqueda de lo nuevo y de lo original, según la confianza en la creación individual, con la "puesta en obra de la verdad" el arte sufre una modificación radical, en cuanto a su consideración más amplia, puesto que ahora abandona esa búsqueda al hacerse innecesaria la categoría de lo nuevo, en circunstancias que ella es apertura de un mundo, en el sentido de la posibilidad tanto de acceder cuanto de interpretar lo ente.

\section{Referencias bibliográficas}

Binns, Niall (1999), "La postmodernidad". Un vals sobre un montón de escombros. Alemania: Peter Lang.

Burke, Peter (ed.) (2003), Formas de hacer historia. Madrid: Alianza. 
Calinescu, Matei (1991), "Sobre el posmodernismo". 5 caras de la modernidad. Madrid: Tecnos.

Danto, Arthur (1989), Historia y narración. Ensayos de filosofía analítica de la historia. Barcelona: Paidós.

Deleuze, Gilles (2005), Lógica del sentido. Barcelona: Paidós.

Foucault, Michel (1999), "Espacios diferentes”, en Estética, ética y hermenéutica. Barcelona: Paidos, pp. 431-441.

Heidegger, Martín (1935/36), Der Ursprung des Kunstwerkes. "El origen de la obra de arte", en Caminos de Bosque. Trad. Helena Cortés y Arturo Leyte. Madrid: Alianza, 1995, pp. 11-74.

Jameson, Frederic (2001), Teoría de la posmodernidad. Trad. Cecilia Montolío y Ramón del Castillo. Madrid: Trotta.

Lyotard, Jean-François (2000), La condición postmoderna. Informe sobre el saber. Trad. Mariano Antolín Rato. Madrid: Cátedra.

Oñate, Teresa (1990), "Sintonía y Diálogo con una ontología actual. Las voces del presente", "Ironía y riesgo del pensamiento débil. La voz oscilante del último hombre", La sociedad transparente. Barcelona: Paidós.

Paz, Octavio (1987), Los hijos del limo. Del romanticismo a la vanguardia. Barcelona: Seix Barral.

Toro, Alfonso de (1997), "Fundamentos epistemológicos de la condición contemporánea: postmodernidad, postcolonialidad en diálogo con Latinoamérica", Postmodernidad y postcolonialidad: breves reflexiones sobre Latinoamérica. Madrid: Iberoamericana.

Vattimo, Gianni (1990), La sociedad transparente. Trad. Teresa Oñate. Barcelona: Paidós.

(2000). El fin de la modernidad. Nihilismo y hermenéutica en la cultura posmoderna. Barcelona: Gedisa. 